\title{
Nocturnal attacks on nearshore fishes in southern California by crustacean zooplankton
}

\author{
Carol A. Stepien ${ }^{1} \&$ Richard C. Brusca ${ }^{2}$ \\ ${ }^{1}$ Department of Biological Sciences, University of Southern California, Los Angeles, California 90089, USA \\ ${ }^{2}$ Natural History Museum, Los Angeles County, Los Angeles, California 90007, USA
}

\begin{abstract}
Adult nearshore fishes in large cages on the seafloor off southern California mysteriously died within 3 to $4 \mathrm{~h}$ after sunset. Night diving observations showed that fishes were attacked by swarms of crustacean zooplankton, primarily the luminescent ostracod Vargula tsujii Kornicker \& Baker 1977 (Myodocopida: Cypridinidae) and the isopod Cirolana diminuta Menzies 1962 (Cirolanidae), species previously identified as members of the southern California demersal zooplankton assemblage. Experiments using traps baited with live fishes showed that attacks occur year-round on many species of nearshore fishes, in both sandy and rocky habitats, and on adults of both sexes more frequently than on juveniles. Ostracods were attracted to fishes first, attaching to their sides and opercula, but not alone causing serious injury. Cirolanid isopods later invaded the traps and were responsible for the fish deaths, usually through extensive gill damage. Both ostracods and isopods often invaded the gills, and also often entered the body cavity through the anus, consuming gonads and liver. Laboratory maze experiments showed that ostracods are attracted to chemicals released from sexually mature fishes and by their own bioluminescence. Isopods are attracted to chemicals released by injured fishes, thus they may preferentially attack fishes initially injured by ostracods. $V$. tsujii also clustered around unrestrained fishes at night in situ; fishes resting near the seafloor periodically shook off the ostracods and sometimes moved to other locations when surrounded by large numbers. Other fishes apparently avoid the ostracods by swimming higher into the water column, burying themselves in sand, or hiding in rock crevices. Emergent crustacean zooplankton may significantly influence nocturnal versus diurnal distributions and behavior of nearshore fishes. Surveys of commercial fishermen indicated that crustacean zooplankton also cause extensive damage to fishes caught in gill nets, often rendering a significant percentage of a catch unmarketable. Evolutionary and ecological aspects of the phenomenon are discussed.
\end{abstract}

\section{INTRODUCTION}

Hypotheses explaining why some species of demersal zooplankton rise into the water column at night, where they are very vulnerable to predation, have often been suggested but not yet empirically tested (Hobson \& Chess 1976, Alldredge \& King 1977, Hammer 1981). Diel migrations of demersal zooplankton have been found to constitute a major feature of many nearshore temperate and tropical habitats, including kelp forests (Hobson \& Chess 1976, Hammer \& Zimmerman 1979, Hammer 1980, 1981, Hobson et al. 1981, Stepien 1982, 1983a, b), subtidal sand flats (Alldredge \& King 1980), eelgrass beds (Robertson \& Howard 1978), and coral reefs (Emery 1968, Alldredge \& King 1977. Porter \& Porter 1977, Hobson \& Chess 1979). These zooplankton either burrow or hide within the benthos during the day, emerging primarily at dusk to travel up into the water column, only to return before dawn. It has been postulated that such demersal zooplankton influence the distributions, activity patterns, and behavior of many nocturnally-active fishes in these habitats (Hobson \& Chess 1976, 1979, Hobson et al. 1981). Nocturnal migrating zooplankton assemblages in both temperate and tropical habitats are dominated by crustaceans, including copepods, ostracods, amphipods, isopods, mysids, cumaceans, decapod larvae, and shrimp.

Demersal zooplankton species entering the water column at night face an increased risk of predation in comparison with non-migrating individuals (Hobson 1974). A majority of nocturnally-active fishes in temperate kelp beds and tropical reefs feed primarily on these migrating forms (Starck \& Davis 1966, Hobson 
1974, Hobson \& Chess 1976, 1979, Alldredge \& King 1977. Hobson et al, 1981). There is probably a strong counterbalancing selective advantage to such diel movement. The functional significance of their migrations has been postulated to include dispersal, feeding, reproduction, molting, and niche diversification (Hobson \& Chess 1976, Robertson \& Howard 1978, Alldredge \& King 1980). Alldredge \& King (1977, p. 332) comment, 'Since the abundance and natural history of resident plankton is practically unknown, this role is not clearly understood'.

Recently, Stepien (1982, 1983a, b) discovered that some species of migrating crustacean zooplankton in southern California nearshore habitats attack live fishes at night. These zooplankton, primarily ostracods and isopods, surround and bite adult fishes located near the benthos, much like swarms of biting dipteran insects. This paper describes the results of quantitative trap experiments, field and laboratory observations, and maze attraction experiments which tested the conditions under which these attacks occur and which species and life stages of fishes are affected. The data suggest that migrating crustacean zooplankton may significantly influence nocturnal distributions and behavior of nearshore fishes.

\section{History of the problem}

While conducting an in situ caging study in July 1982 at Santa Catalina Island, California (Fig. 1), adult giant kelpfish Heterostichus rostratus Girard were found to die overnight (Stepien 1982, 1983a, b, Cohen 1983). The kelpfish had been placed in $1 \mathrm{~m}^{3}$ cages constructed of $1.3 \mathrm{~cm}$ plastic Vexar mesh surrounded by a frame of PVC piping. The cages also contained

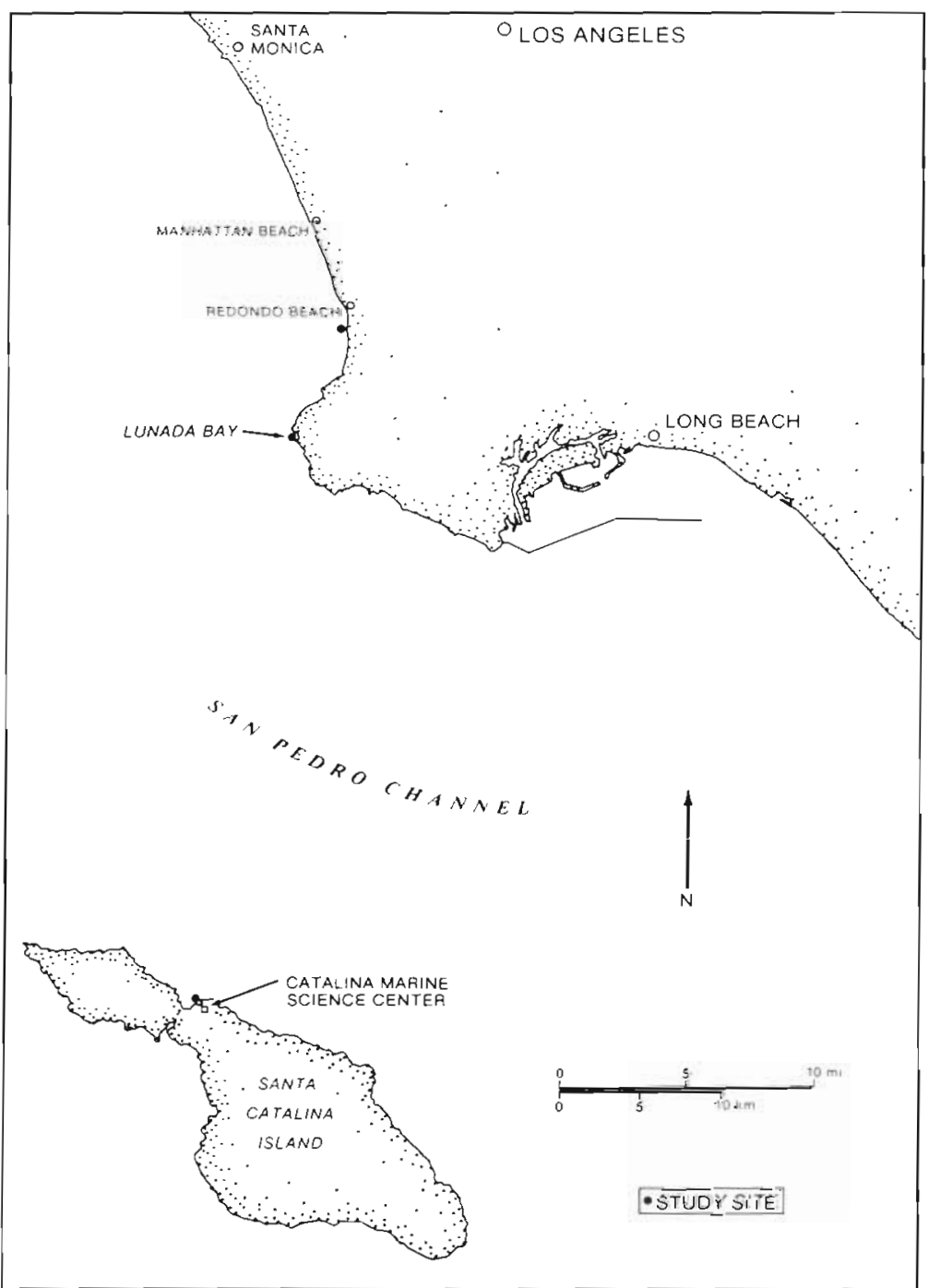

Fig. 1. A portion of the southern California coastline in the vicinity of Los Angeles, showing study sites at Santa Catalina Island, Lunada Bay (on the Palos Verdes Penninsula), and Redondo Beach 
rocks and algae, simulating natural habitats, and were placed 7 to $10 \mathrm{~m}$ deep on the seafloor near a kelp forest area. Adult kelpfish contained in the same cages in large outdoor laboratory aquaria survived in good health for months. The mesh size was large enough to allow entry of small fishes and crustaceans, upon which kelpfish feed. It was small enough, however, to exclude any large predators.

Juvenile kelpfish, in contrast to adults, survived in good health for months during field cage experiments located in the same areas. Juvenile kelpfish were contained in smaller cages of similar design, $0.3 \mathrm{~m}^{3}$ in size and with $0.6 \mathrm{~cm}$ mesh. Juveniles placed in the larger adult cages were not killed whereas adults placed in the smaller juvenile-sized cages still died overnight. When observed in the cages during the day, all kelpfish appeared to behave and feed normally. Nevertheless, if caged overnight in either sandy or rocky habitats, adult kelpfish were usually dead by morning. Some of the dead fish had no apparent external lesions, whereas others had apparently been heavily attacked by microcrustaceans (Fig. 2A). All of the dead fish had some gill damage and most had their gonads and livers consumed, but usually not the gut or body musculature.

Night SCUBA dives were made to discover what was causing the deaths. Adult kelpfish were observed to be surrounded by swarms of attacking crustacean zooplankton. The zooplankton appeared to behave much like swarms of biting dipterans in terrestrial systems. Juvenile kelpfish in nearby cages were not surrounded by the zooplankton. Crustaceans also bit the divers in exposed areas of the face and hands, the bites feeling much like horsefly bites. Ostracods attached in clusters along the sides of the kelpfish. Attacking crustaceans were captured and identified as the luminescent cypridinid ostracod Vargula tsujii Kornicker \& Baker 1977 (Fig. 2B) and the cirolanid isopod Cirolana diminuta Menzies 1962 (Fig. 2C) (Stepien 1982, 1983a, b, 1985). These species have previously been described as nocturnally emergent zooplankton which hide in sand, cobble, or kelp holdfasts during the day and enter into the water column at night (Hanmer \& Zimmerman 1979, Hammer 1980, 1981, V. tsujii as $V$. americana in Hobson \& Chess 1976).

Numerous species of isopods in the family Cirolanidae, and in related families, are known scavengers and occasional micropredators on fishes (for summaries see Moreira \& Sadowsky 1978, Kussakin 1979, Brusca \& Iverson 1985). Similarly, ostracod species of the family Cypridinidae have been reported as occasional scavengers or 'biters' or actual parasites on other marine animals (Monod 1923, Harding 1966, Felder 1982, Cohen 1983, Kretzler 1984). However, previous reports on these crustaceans have been largely anecdotal and until now no quantitative or rigorous experimental studies have been undertaken on these phenomena.

In the present study quantitative trap experiments were designed to test the conditions under which attacks by demersal crustacean zooplankton occur, and which species and life stages of fishes are affected. Laboratory behavioral experiments on the attraction of the crustacean zooplankton to fishes were also conducted. Night SCUBA diving observations were made to determine whether these attacks also occur on unrestrained fishes in situ and by what means fishes may avoid these attacks. Finally, a survey of commercial fishermen and fisheries biologists was conducted to seek evidence of damage to commercial fisheries caused by demersal crustacean zooplankton.

\section{METHODS}

Quantitative trap experiments. These were designed (Fig. 2D) using weighted $9.5 \mathrm{l}$ plastic buckets to test which species and life history stages of fishes were attacked and in what types of habitats. Two $14 \times 5^{1 / 2}$ $\mathrm{cm}$ panels, covered with $800 \mu \mathrm{m}$ plastic Vexar mesh and located $14.5 \mathrm{~cm}$ from the bottom of the buckets, served as an entrance for the zooplankton while keeping larger organisms out. Two $13 \times 3 \frac{1 / 2}{2} \mathrm{~cm}$ panels, covered with $100 \mu \mathrm{m}$ mesh and located $7 \mathrm{~cm}$ from the bottom of the buckets, allowed drainage while keeping the samples intact.

Empty control traps were tested simultaneously with traps baited with a single live fish of various species, size, and sex. Experiments were also conducted using dead fish and squid. Traps were usually set at sunset and left out for $2 \mathrm{~h}$, an interval determined to be appropriate for heavy attacks on live fishes, but not resulting in deaths. Adult kelpfish, Heterostichus rostratus, were found in preliminary experiments to die within 3 to $4 \mathrm{~h}$ after sunset (Stepien 1982, 1983a, b, 1985).

After experimental runs, plankton from the buckets were washed into sample jars and preserved. Fishes from the experiments were examined carefully for attached zooplankton, including ones located in their gill chambers. These were removed and preserved, and the fishes then sacrificed, sexed, and body cavities examined for zooplankton. The zooplankton were later identified and counted under a dissection microscope.

Trap experiments were conducted in sandy and rocky nearshore habitats ranging from 3 to $35 \mathrm{~m}$ deep, near the University of Southern California's Catalina Marine Science Center (CMSC) on Santa Catalina Island, approximately $36 \mathrm{~km}$ off Los Angeles, Califor- 


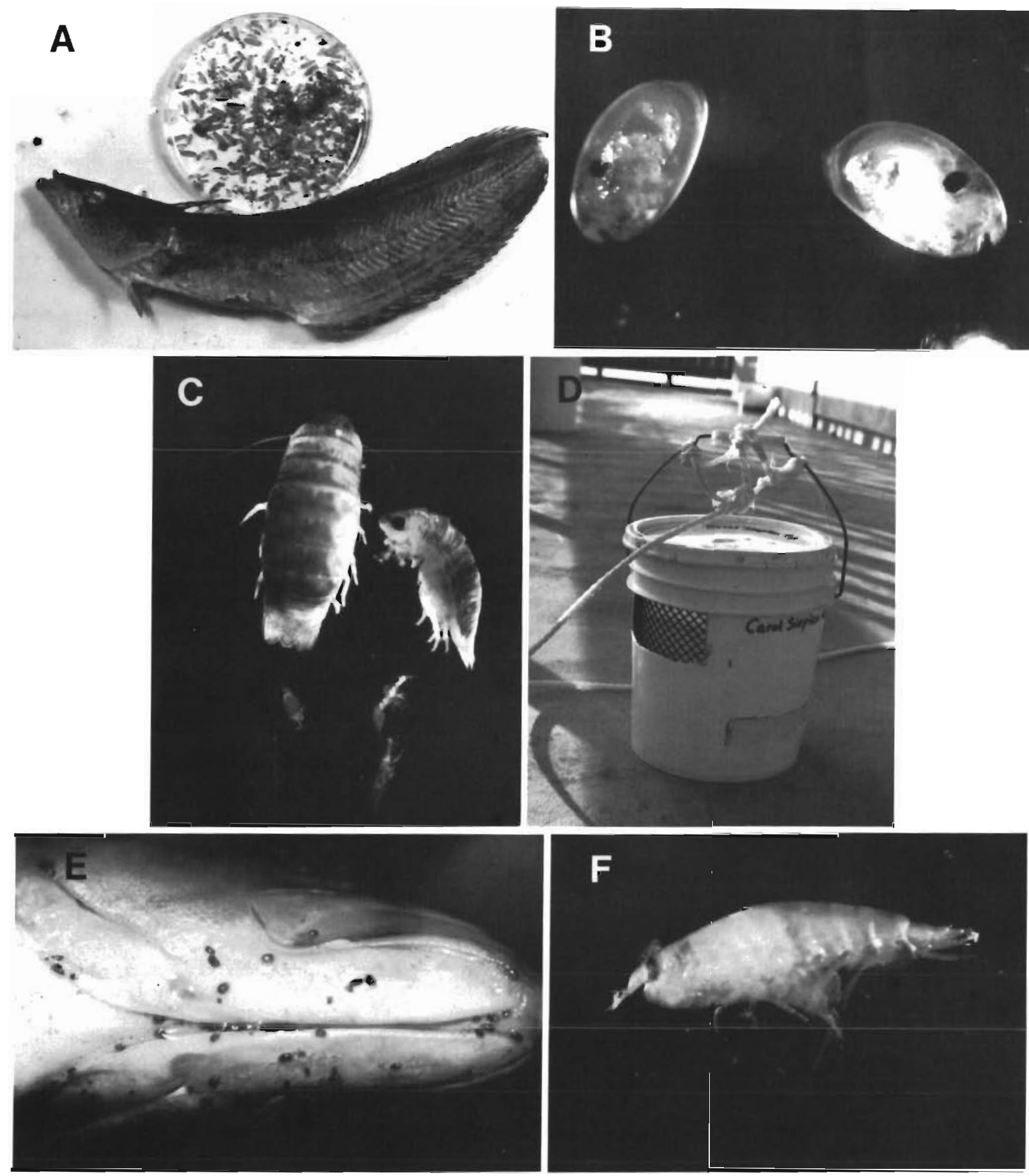

Fig. 2. (A) Kelpfish (Heterostichus rostratus) after 1 night in a demersal cage experiment; Petri dish contains numerous isopods (Cirolana diminuta), ostracods (Vargula tsujii), and amphipods (Lysianassa holmesi) taken from body cavity of fish. (B) The luminescent ostracod $V$. tsujii (1 mm in length) from trap experiments containing live fish. (C) The isopod C. diminuta (top, 2.3 $\mathrm{mm}$ in length) from trap experiments containing live fish; the small isopods in lower part of photo are female Gnathia sp. (family Gnathiidae), which are known fish micropredators and were occasionally found in the trap experiments. (D) Quantitative trap design for field experiments. (E) Ostracods $V$. tsujii attacking live kelpbass Paralabrax clathratus (ventral view of isthmus region). (F) The gammarid amphipod $L$. holmesi $(1.5 \mathrm{~mm}$ in length) from trap experiments containing live fish 
nia (Fig. 1). Experiments were conducted in Big Fishermen's Cove, Chalk Cliffs Cove, and near the laboratory's seawater intake pipes, from July 1982 through March 1984. Trap experiments were also conducted in August and September 1983 in a kelp-bed area at Lunada Bay, Palos Verdes, and in a muddy bottom habitat off Redondo Beach, both near the Los Angeles mainland (Fig. 1).

Fishes for the trap experiments were collected using hand nets while SCUBA diving or using a rod and reel. Only fishes which were undamaged and appeared in excellent health were used in the experiments. Kelpfish were tested in all initial experiments. Several other fish species common in kelp bed areas were also tested. At least 1 adult male, 1 adult female, and 1 juvenile of each species were tested. These included senorita Oxyjulis californica Ayres (Labridae), rock wrasse Halichoeres semicinctus Ayres (Labridae), sheephead Semicossyphus pulcher Ayres (Labridae), black surfperch Embiotoca jacksoni Agassiz (Embiotocidae), opaleye Girella nigricans Ayres (Kyphosidae), blacksmith Chromis punctipinnis Cooper (Pomacentridae), and kelpbass Paralabrax clathratus Girard (Serranidae).

Kelpbass and rock wrasse were selected as key species because (like kelpfish) they were easy to collect and highly attractive to crustacean zooplankton. Individuals of these 2 species were tested in some experiments along with kelpfish to determine under what conditions the attacks occurred. In experiments where differences between the 3 species were determined to be negligible, results were grouped in data analysis.

Kelpfish of sizes $16 \mathrm{~cm}$ TL (total length) and smaller were classified as juveniles, while those larger than or equal to $18 \mathrm{~cm}$ TL were classified as adults (Stepien 1985). Rock wrasse measuring $10 \mathrm{~cm}$ TL and smaller were classified as juveniles, while those of at least 14 cm TL were classified as adults (Fitch \& Lavenberg 1975). Similarly, kelpbass less than or equal to $20 \mathrm{~cm}$ TL were classified as juveniles, while those of at least $26 \mathrm{~cm}$ TL were classified as adults (Fitch 1974). Estimates of sexual maturity were confirmed by examining gonads after the experiments.

The following quantitative trap experiments were conducted in the field:

(1) Numbers of crustacean zooplankton attracted to adult fishes versus empty control traps. Traps were located over a sandy substrate. Kelpfish, rock wrasse, and kelpbass were tested.

(2) Numbers of crustacean zooplankton attracted to adult fishes in traps located over a sandy substrate versus a rocky substrate. Kelpfish, rock wrasse, and kelpbass were tested.

(3) Numbers of crustacean zooplankton attracted to adult fishes in midwater traps located $3.3 \mathrm{~m}$ off a sandy bottom versus traps located on the bottom. Kelpfish, rock wrasse, and kelpbass were tested. The same individuals were tested in experiments run on 2 consecutive nights, the first in midwater, the second on the bottom

(4) Numbers of crustacean zooplankton attracted to traps containing juvenile versus adult fishes. Kelpfish, rock wrasse, and kelpbass were tested.

(5) Numbers of crustaceans attracted to adult male versus adult female fishes. Sexually dimorphic color patterns were used to initially separate male from female kelpfish (Stepien 1985) and rock wrasse (Eschmeyer et al. 1983). Fishes were sacrificed after experiments for sexing.

(6) Timing of attraction of the various crustacean zooplankton to traps baited with live adult fishes. Traps were left out for 1 and $2.5 \mathrm{~h}$, respectively, on 2 consecutive nights. Kelpfish alone were tested in this experiment.

Unless otherwise indicated, experimental traps were set $0.5 \mathrm{~m}$ above sandy bottom locations, 8 to $10 \mathrm{~m}$ in depth. Results of trap experiments were analyzed using Student's T-Test and $95 \%$ confidence intervals (Sokal \& Rohlf 1981). T-values were considered significant only if less than or equal to the 0.05 alpha level, although values less than or equal to a 0.10 alpha level are also noted on graphs of results.

Field observations. In situ observations on uncaged fishes were made during night SCUBA dives at Santa Catalina Island to determine whether they also attracted the crustacean zooplankton. Approximately $15 \mathrm{~h}$ of night-time observations were made. Ostracods and isopods near and on the fishes were readily observable using a dim underwater light. Behavior of the fishes, activity levels, and locations were recorded. These observations were compared to $50 \mathrm{~h}$ of day observations. Behavior of fishes confined in trap experiments at night was also recorded.

Laboratory behavioral experiments. Crustacean zooplankton attraction to, and attacks on, fishes were observed in laboratory aquaria at night. Positions of crustaceans in relation to fishes were noted along with fish behavior. Sixteen attacks on 6 different species (kelpfish, kelpbass, rock wrasse, senorita, opaleye, and sheephead) were recorded. Maze experiments were also conducted, which tested ostracod (Vargula tsujii) and isopod (Cirolana diminuta) attraction to kelpfish.

Maze design consisted of a $4 \times 20 \mathrm{~cm}$ plexiglass container, in which zooplankton were placed centrally between 2 movable glass plates and experimental and control choices placed at opposite ends of the maze. The maze was filled with clean filtered seawater, which was changed between experimental runs. Groups of 10 to 15 ostracods or 4 to 8 isopods were 
placed behind the central partitions. Each experiment was repeated at least 10 times, using new groups of ostracods or isopods each time. Experimental and control ends were alternated for each experimental trial. Ostracod and isopod attraction to the following stimuli were tested in these maze experiments:

(1) Attraction to ostracod luminescence: 30 ostracods were placed in a glass jar at 1 end of the maze. An empty glass jar was placed in the control end. Both jars were taller than the water level of the maze, preventing possible chemical stimuli from leaking into the water. These experiments were conducted in a darkened room at night. The jars were stirred with wooden rods to induce ostracod luminescence.

(2) Chemical attraction to ostracods: 30 ostracods were placed in a plastic jar in which a large panel had been cut in 1 side and $100 \mu \mathrm{m}$ mesh glued in the opening. This jar was placed in the experimental end. An empty jar of identical design was placed in the control end. Experiments were conducted in a lighted room to eliminate any attraction to luminescence.

(3) Attraction to chemicals released by an adult sexually-mature fish: a female kelpfish was placed in a $9.5 \mathrm{l}$ bucket containing clean filtered seawater for $2 \mathrm{~h}$ prior to the experiments. As a control, a bucket of clean filtered water was treated similarly, but without introducing a fish. Both buckets were aerated. Twelve drops each of experimental water and control water were simultaneously introduced into the center of the water column in the respective ends of the maze.

(4) Attraction to chemicals released from injured fish: the female kelpfish from experiment 3 was injured by making several skin lacerations with a sharp knife. The procedure described in Experiment 3 was then repeated.

All of the experiments were observed 5 min after the stimuli were introduced. The number of ostracods or isopods in the experimental and control halves of the maze were counted. All experiments, unless otherwise indicated, were conducted in a lighted room at night. Data from these experiments were analyzed using chisquare tests and 0.05 alpha levels (Sokal \& Rohlf 1981).

Survey of commercial fishermen. A survey of commercial fishermen and fisheries biologists was conducted to document whether crustaceans occurring in the water column damaged commercially-important fishes caught using gill nets. Such damage has been reported in Japanese gill net fisheries (Sekiguchi et al. 1981, Sekiguchi 1982) and is well known to Pacific coast fishermen, although only anecdotally described in scientific literature (Robson Collins \& A. Rucker Hartmann pers. comm.). Contacts with fishermen were established through the California Department of Fish and Game and the California Gillnetters Association. Sixteen responses were obtained from the surveys.

\section{RESULTS}

\section{Description of the attacks}

Field and laboratory observations consistently showed the ostracod Vargula tsujii to be the first crustacean attracted to the fishes. The ostracods clustered in large numbers along the sides of the fishes, particularly along the dorsal and anal fin bases, around the anus, and along the opercula in both laboratory and field observations. Ostracods alone did not inflict any visible damage or scale loss. They were easily dislodged with a squirt bottle of seawater.

Fishes which had been attacked by only ostracods survived in good health indefinitely when kept in laboratory aquaria after removal of these crustaceans. The ostracods appeared to feed on mucus and small pieces of fish skin. They often remained on the fishes for long periods of time. Fishes were able to dislodge the ostracods by shaking them off, although when only ostracods were present in laboratory or cage experiments this behavior did not always occur. Some caged fishes remained quiescent even with hundreds of ostracods on them.

Experimental buckets containing large numbers of ostracods glowed brightly with their blue luminescence when the traps were raised from the water. Vargula tsujii, in underwater and laboratory observations, luminesced continuously for several minutes, rather than emitting individual flashes. They luminesced both spontaneously and when physically disturbed, such as when contacting divers or other objects. Only some of those observed in the field trap experiments luminesced when alighting on the fishes.

The cironalid isopod Cirolana diminuta appeared to inflict the major damage. These isopods entered the traps after the major influx of ostracods. They were observed to bite the fishes in both laboratory and field experiments. Once isopods were present in the traps, fishes exhibited great distress, thrashing about in apparent attempts to dislodge them. Isopods could not be removed with a squirt bottle (as could ostracods) and had to be picked off with forceps.

The isopods often chewed through the anal opening of the fishes and were subsequently found inside the body cavity. Invasion of the body cavity was usually indicated by a ragged enlargement of the anal opening and/or swelling and necrosis around the opening. Once the body cavity was entered, gonads and liver were ususally wholly or partly consumed by the isopods. When live fishes were sacrificed after the trap experiments, there were often no gonads or liver remaining. The body musculature was usually undamaged, except in the heaviest attacks. Additionally, in most moderate to heavy attacks isopods invaded the 
gills causing extensive damage to gill filament tissues. Isopods were also found in the mouth and throat regions. Ostracods and amphipods were also often found inside fishes that had been heavily damaged, along with the isopods.

A gammarid amphipod, Lysianassa holmesi Barnard 1955 (Fig. 2F) was also attracted to live fishes in trap experiments. Amphipod occurrence, however, was more irregular and unpredictable than that of ostracods and isopods. L. holmesi was usually, but not always, present during heavy isopod attacks. The amphipods tended not to cluster or alight on the fishes themselves, but appeared to feed on dislodged mucus and scales in the traps. They were, however, occasionally found inside the body cavity of heavily-damaged fishes.

Although other plankton species were occasionally collected in the trap experiments, only Vargula tsujii, Cirolana diminuta, and Lysanassa holmesi were found regularly and in large numbers. A few traps attracted gnathiid isopod (Gnathia sp.) juveniles and females (Fig. 2C). Juvenile gnathiids are known fish parasites (Sars 1897, Richardson 1904, Kussakin 1979). Some traps also attracted a few decapod crustacean larvae and shrimps, irregularly and in very low numbers.

\section{Quantitative trap experiments}

Live adult kelpfish attracted significantly larger numbers of ostracods (Vargula tsujii), amphipods (Lysianassa holmesi), and isopods (Cirolana diminuta) than did empty control traps (Fig. 3A). These results were also true for grouped data of key fish species, including kelpbass (Paralabrax clathratus) and rock wrasse (Halichoeres semicinctus), as well as kelpfish (Fig. 3B). Control traps containing a dead adult kelpfish attracted significantly more ostracods (but not isopods or amphipods) than did traps containing an equal weight of dead squid (Fig. 3C).

Attacks occurred year-round, did not vary significantly with lunar cycle (Table 1), and varied little seasonally. Adults of all 8 species of common nearshore fishes tested in the trap experiments attracted the crustaceans. These included members of the families Clinidae, Labridae, Kyphosidae, Embiotocidae, Pomacentridae, and Serranidae (see 'Methods').

Although the numbers of crustaceans attacking adult fishes differed somewhat in rocky versus sandy habitats, these differences were not significant (Fig. 4). Attraction did not vary significantly among depths tested, ranging from 3 to $35 \mathrm{~m}$. Experiments located on sand and rock bottoms at Lunada Bay, California also attracted all 3 species of crustaceans. Fishes in experi-
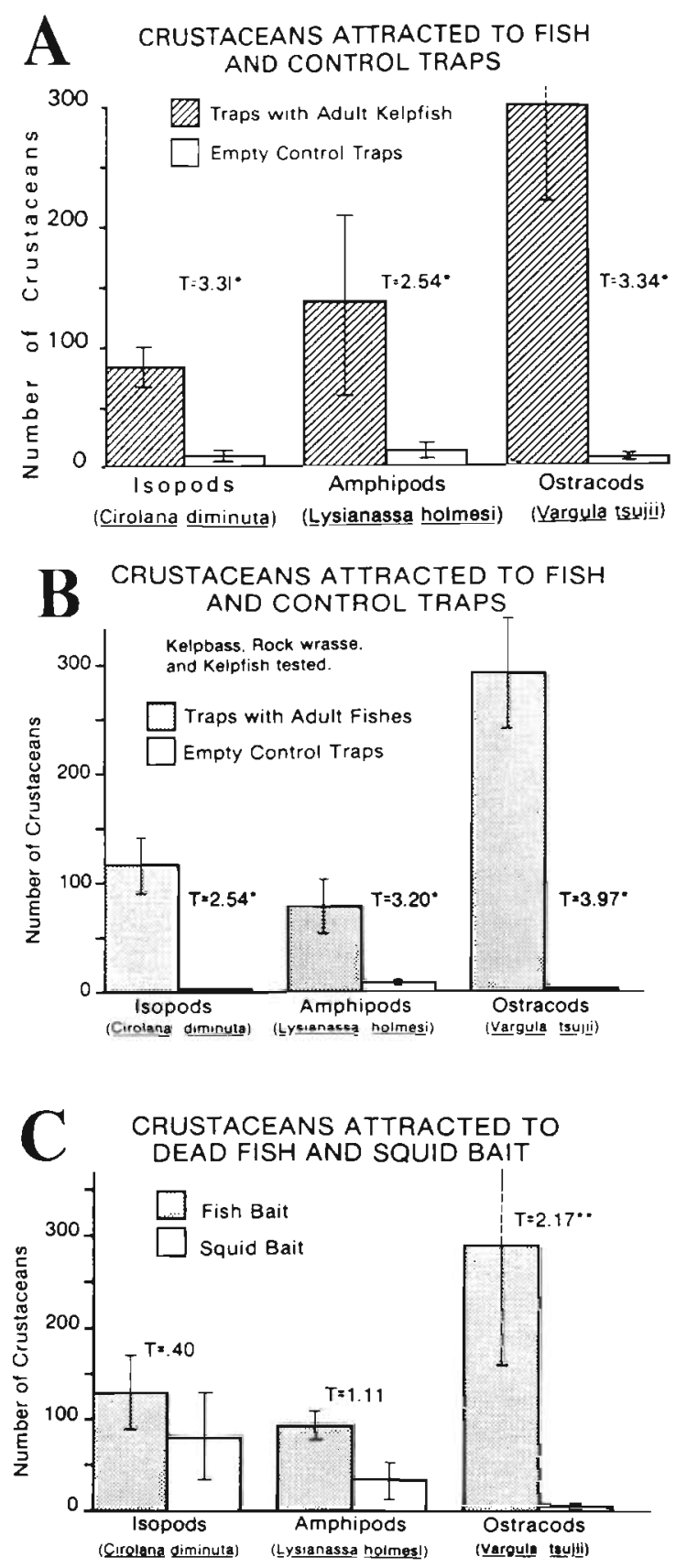

Fig. 3. Crustacean zooplankton attracted to experimental baited and unbaited traps; standard error bars and Student $T$ Test values indicated. (A) Experimental traps containing 1 live adult kelpfish each versus empty (control) traps $(\mathrm{N}=24$, - $\mathrm{p} \leq$ 0.05). (B) Experimental traps containing 1 live adult fish each, including 10 kelpbass, 10 rock wrasse, and 24 kelpfish (data combined), versus empty (control) traps $\left(\mathrm{N}=44,{ }^{\circ} \mathrm{p} \leq\right.$ 0.05). (C) Experimental traps baited with 1 dead kelpfish each versus an equal weight of dead squid bait $(\mathrm{N}=10, \cdots$ significant at 0.1 level)

ments on a mud bottom off Redondo Beach, California, however, did not attract any of the crustacean zooplankton. 

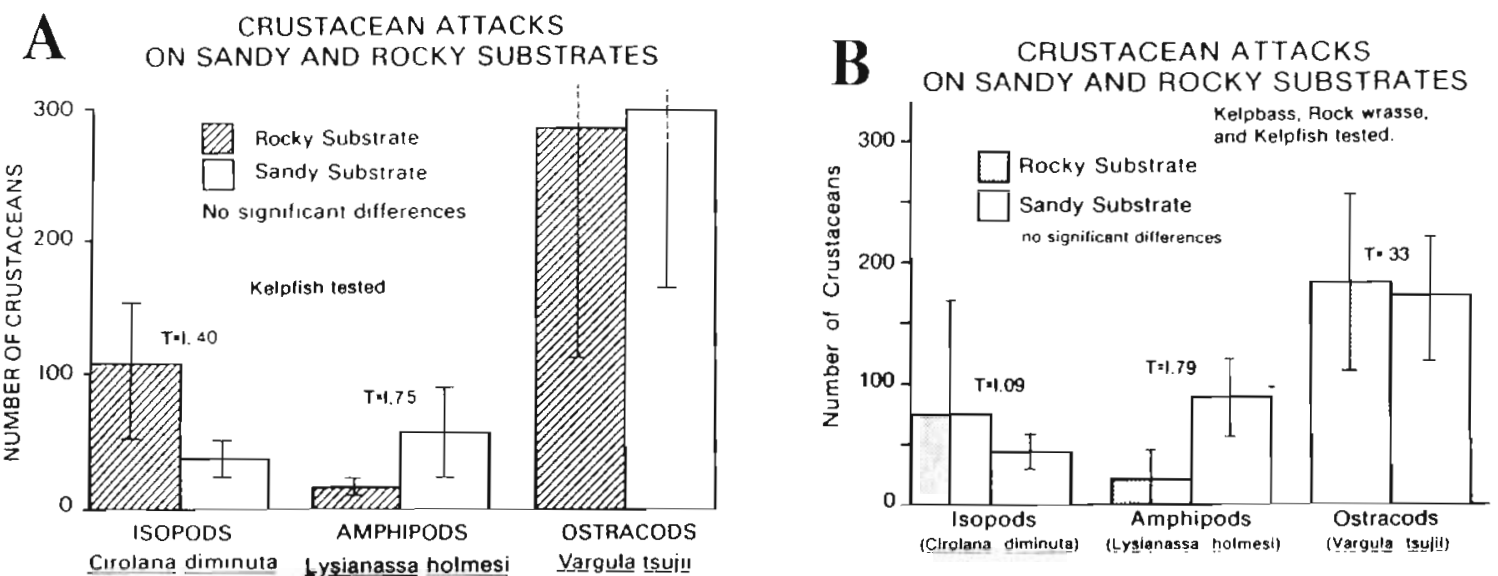

Fig. 4. Number of crustacean zooplankton attracted to live adult fishes in experiments located off sandy substrates versus rocky substrates. Standard error bars and Student T-Test results indicated. (A) Traps containing 1 kelpfish each $(\mathrm{N}=10)$. (B) Traps containing 1 live fish each (grouped data), including 6 kelpbass, 8 rock wrasse, and 10 kelpfish $(N=24)$

Adult fishes in midwater traps ( $3.3 \mathrm{~m}$ off the seafloor) attracted significantly fewer numbers of astracods and isopods than did the same fishes placed in traps on the bottom (Fig. 5). Amphipod attraction differences in this experiment were significant only at the 0.10 alpha level.

Adult fishes in bottom traps attracted significantly greater numbers of ostracods and isopods than did

Table 1. Dates and lunar periods when various trap experiments were conducted

\begin{tabular}{rlllrl|}
1 & 30 Aug 82 & First quarter & 14 & 11 Mar 83 & Last quarter \\
2 & 11 Sep 82 & Last quarter & 15 & 12 Mar 83 & Last quarter \\
3 & 15 Sep 82 & Last quarter & 16 & $2 \mathrm{Apr} 83$ & Last quarter \\
4 & 24 Sep 82 & First quarter & 17 & $3 \mathrm{Apr} 83$ & Last quarter \\
5 & 13 Nov 82 & Last quarter & 18 & 14 May 83 & New moon \\
6 & 18 Nov 82 & New moon & 19 & 28 May 83 & Full moon \\
7 & 11 Dec 82 & Last quarter & 20 & 29 May 83 & Full moon \\
8 & 14 Jan 83 & New moon & 21 & 11 Jun 83 & New moon \\
9 & 19 Jan 83 & First quarter & 22 & 1 Jul 83 & New moon \\
10 & 20 Jan 83 & First quarter & 23 & 5 Aug 83 & Last quarter \\
11 & 21 Jan 83 & First quarter & 24 & 21 Aug 83 & Full moon \\
12 & 22 Jan 83 & First quarter & 25 & 27 Aug 83 & Last quarter \\
13 & 10 Mar 83 & Last quarter & 26 & 24 Sep 83 & Full moon \\
& & & & & \\
\hline
\end{tabular}

juveniles (Fig. 6). Males and females attracted roughly equal numbers of crustacean zooplankton (Fig. 7). Fishes with 'ripe' eggs or 'running' spenm attracted the largest numbers of crustaceans and were most severely damaged.

In timed experiments, ostracods were first to attack the kelpfish, with large numbers entering during the first hour after sunset (Table 2). Relatively few isopods and amphipods entered the traps during this time. After $2.5 \mathrm{~h}$, isopods and amphipods had invaded the traps in large numbers and the numbers of ostracods also increased markedly.

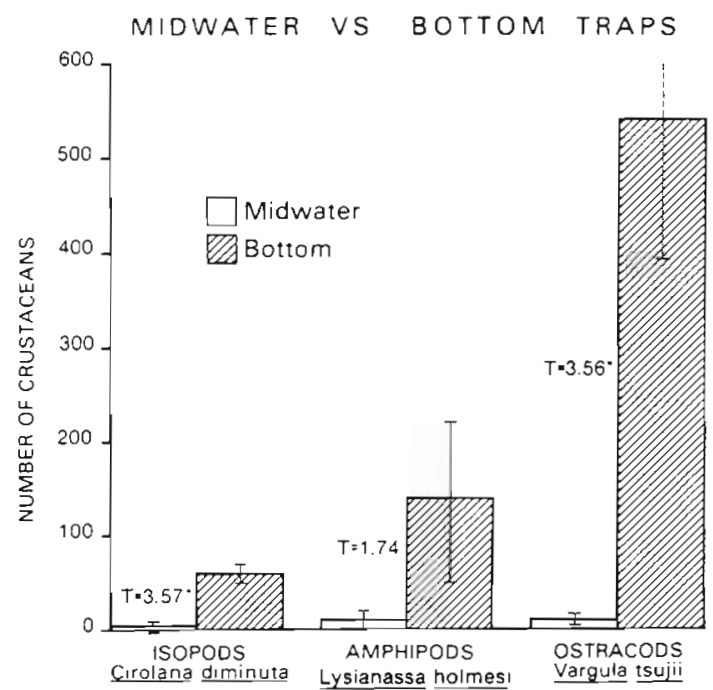

Fig. 5. Mean numbers of crustacean zooplankton attracted to experiments containing 1 live adult fish each, grouped data including 2 kelpbass, 2 rock wrasse, and 6 kelpfish, in midwater traps $(3.3 \mathrm{~m}$ off the bottom) versus bottom traps $(7 \mathrm{~m}$ deep). Standard error bars and Student T-Test values indicated. $(\mathrm{N}=10, \cdot \mathrm{p} \leq 0.05)$

Table 2. Total numbers of crustacean zooplankton attracted to live kelpfish in experimental traps 1 h after sunset versus $21 / 2 \mathrm{~h}$ after sunset, on 2 consecutive nights

\begin{tabular}{|lccc|}
\hline Kelpfish size & Isopods & Amphipods & Ostracods \\
\hline 1 hour & & & \\
$17.0 \mathrm{~cm}$ & 1 & 4 & 20 \\
$25.0 \mathrm{~cm}$ & 0 & 7 & 179 \\
$26.8 \mathrm{~cm}$ & 1 & & 68 \\
$21 / 2$ hours & & & \\
$17.0 \mathrm{~cm}$ & 45 & 89 & 259 \\
$25.0 \mathrm{~cm}$ & 199 & 82 & 53 \\
$26.8 \mathrm{~cm}$ & 80 & 130 & 335 \\
\hline
\end{tabular}



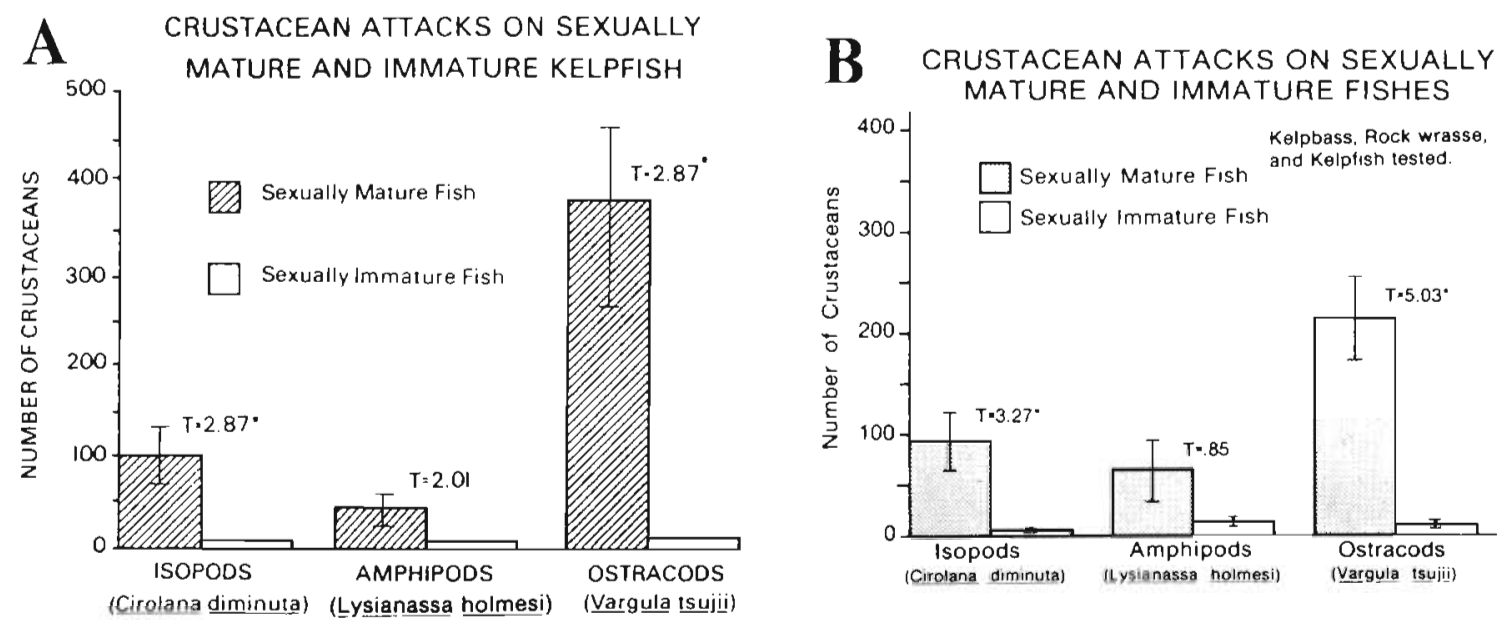

Fig. 6. Mean numbers of crustacean zooplankton attracted to bottom traps containing 1 adult versus 1 juvenile fish each. Standard error bars and Student T-Test values indicated $(\cdot p \leq 0.05)$. (A) Adult versus juvenile kelpfish ( $N=14$ ). (B) Adults versus juveniles, combined data for 6 kelpbass, 8 rock wrasse, and 14 kelpfish $(N=28)$

\section{Field observations}

During night dives, ostracods (Vargula tsujii) and a few isopods (Cirolana diminuta) were observed to cluster around fishes that were resting near the seafloor. Fishes with ostracods on and/or around them included blacksmith Chromis punctipinnis, sand bass Paralabrax sp., kelpbass $P$. clathratus and kelpfish Heterostichus rostratus. Fishes accumulating large numbers of ostracods (20 or more) on their sides periodically shook them off, or, in the cases of some blacksmith and kelpfish, simply swam away to a different nearby location. Only large numbers of ostracods appeared to instigate movement to another location, after shaking was seemingly unsuccessful. A few cirolanid isopods were also observed near these fishes, but never in large numbers.

\section{Laboratory behavioral experiments}

Behavioral maze experiments showed that Vargula tsujii is attracted to its own luminescence, but not to any chemicals released by members of its own species (Fig. 8, Exp. 1 \& 2). Maze experiments indicated that $V$. tsujii is chemically attracted to both healthy and
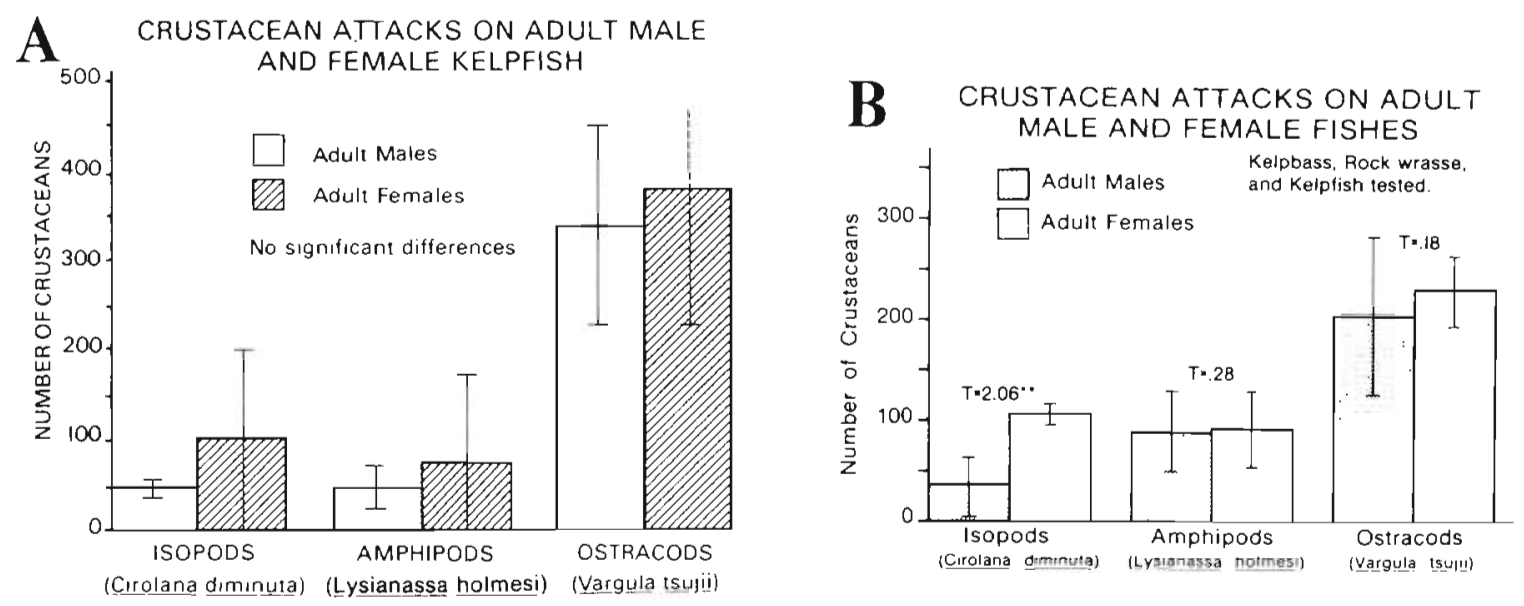

Fig. 7. Mean numbers of crustacean zooplankton attracted to adult male versus adult female fishes in individual trap experiments. Standard error bars and Student T-Test values indicated. (A) Adult male versus adult female kelpfish ( $N=10$ ). (B) Combined data for 6 kelpbass, 6 rock wrasse, and 10 kelpfish; adult males versus adult females $(N=22, \cdots$ significant at 0.01 level) 


\section{OSTRACOD ATTRACTION EXPERIMENTS}

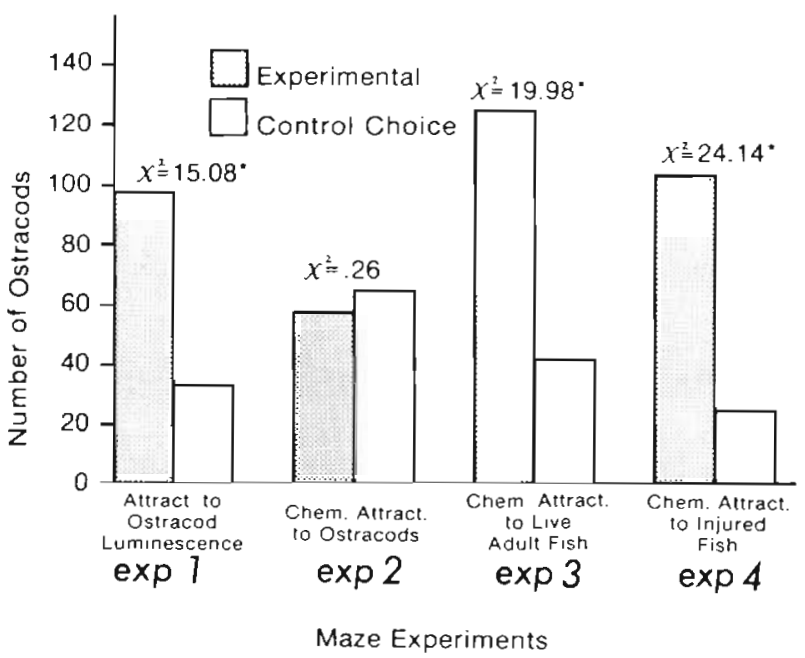

Fig. 8. Vargula tsujii and Heterostichus rostratus. Mean number of ostracods attracted to experimental end versus control end of attraction maze experiment. Data are ungrouped; Chi-square values are indicated; ${ }^{\circ}$ significant at $\leq 0.05$ level. Four experiments are summarized on this figure (see text for discussion of each): $\exp 1, N=133 ; \exp 2, N=122$; $\exp 3, N=165 ; \exp 4, N=126$

injured sexually mature kelpfish (Fig. 8, Exp. 3 \& 4). Behavioral maze experiments testing the isopod Cirolana diminuta indicated that the isopods are not attracted to $V$. tsujii, showing no significant response to either chemicals or light emitted by the ostracods (Fig. 9, Exp. 1 \& 2). Unlike ostracods, isopods were not

\section{ISOPOD ATTRACTION EXPERIMENTS}

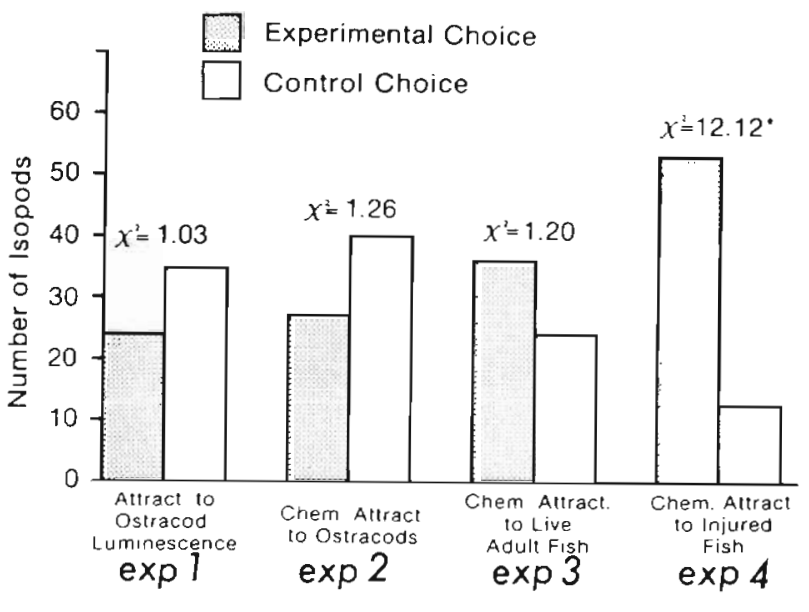

Maze Experiments

Fig. 9. Cirolana diminuta and Heterostichus rostratus. Mean number of isopods attracted to experimental end versus control end of attraction maze experiment. Data are ungrouped;

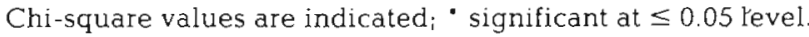
Four experiments are summarized on this figure (see text for discussion of each): $\exp 1, N=59 ; \exp 2, N=67 ; \exp 3, N=60$; $\exp 4, N=66$ attracted to chemicals released from healthy adult kelpfish. The only significant isopod attraction was a chemical attraction to injured kelpfish (Fig. 9, Exp. 3 \& 4).

\section{Survey of commercial fishermen}

Data from 12 commercial fishermen and 4 fisheries biologists indicate that isopod and amphipod damage to fishes captured by commercial gill nets and set line is very common along the Pacific coast. All 16 individuals surveyed had observed damage to fishes caused by isopods and/or amphipods (Table 3 ).

Table 3. Grouped responses from surveys of 16 commercial fishermen and fisheries biologists

(1) Have you experienced and/or observed destruction of commercially important fish species by sand fleas (amphipods) and/or fish lice (isopods)?

$\underline{Y e s}=16$, No $=0$

(2) If so, which types (species) of fishes were attacked by these?

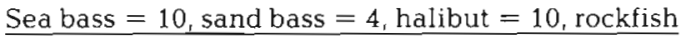
$=5$, lingcod $=2$, red snapper $=4$, bait in lobster traps $=2$

(3) Do these attacks result in the fish being unnarketable?

Yes $=12$, Sometimes $=4$, No $=0$ (Many stated that hagfish, sea lions, and seals also often cause extensive damage to fishes)

(4) Approximately when and under what conditions is this damage most prevalent?

(A) Locations: Responses vary Alaska through San Diego along the Pacific coast

(B) Bottom type: Sand $=10$, rock $=6$, mud $=5$, kelp

(C) Depth: $\quad$ Between 6 and $18 \mathrm{~m}=9$, between 40

(D) Season: $\quad$ Summer $=9$, winter $=6$, spring $=3$, all year $=7$

Survey respondents indicated that several important commercial fishes are seriously affected by isopod and amphipod attacks, including white seabass Cynoscion nobilis Ayres (Sciaenidae), sand bass Paralabrax spp. (Serranidae), California halibut Paralichthys californicus Ayres (Bothidae), rockfish Sebastes spp. (Scorpaenidae), lingcod Ophiodon elongatus Girard (Hexagrammidae), and red snapper Sebastes spp. (Scorpaenidae). Tony West (pers. comm.) has often observed these attacks to commence while the fish were still alive but restrained by nets. Areas affected by the attacks range at least from Alaska to San Diego. Sandy bottoms were most often cited as being affected, although attack incidents on rock, kelp, and mud bot- 
toms were also common. Depths where attacks occurred ranged from 6 to $18 \mathrm{~m}$, although some attacks were also cited between 40 and $100 \mathrm{~m}$, particularly in northern waters. These attacks appear to be common yearround, with inconsistent seasonal variations in some areas (Table 3).

\section{DISCUSSION}

The luminescent myodocopid ostracod Vargula tsujii was the first zooplankton species attracted to live fishes in the trap experiments. One of the original type series of $V$. tsujii was collected by E. S. Hobson from the body of the pomacentrid fish Chromis atrilobata Gill in La Jolla, California (Kornicker \& Baker 1977). Other cypridinids reported feeding on live and dead fishes (Monod 1923, Harding 1966) may have attacked individuals injured during collection. Live myodocopid ostracods (Skogsbergia lerneri) were collected from the gills of a dead hammerhead shark in Belize, but may have attacked the animal only after it was dead or dying (Cohen 1983). Tropical ostracods also appear capable of attacking live animals, however, similar to $V$. tsujii. G. Hendler described an attack by cypridinids from the San Blas Islands, Panama, on his diving buddy at night (Cohen 1983).

Laboratory maze experiments showed that Vargula tsujii was attracted to chemicals released by healthy, sexually mature fishes. The lack of attraction to juvenile fishes suggests that the ostracods may be cueing on chemicals released from the gonads of mature fishes. They were also attracted to the luminescence of other conspecific individuals. Incidental laboratory experiments showed no attraction to a blue or green filter-covered flashlight. $V$. tsujii was attracted in large numbers to chemicals released from injured adult fishes. Results of field and laboratory experiments indicated that although ostracods cause only minor damage to the fishes, these injuries may serve to attract amphipods and isopods, the latter being capable of inflicting considerable damage.

Both laboratory and field experiments indicated that the isopod Cirolana diminuta, which invaded traps after the ostracods, caused most of the damage to the fishes. C. diminuta has often been misidentified as $C$. parva Hansen 1890 in California waters. These 2 species were synonymized by Menzies \& Glynn (1968) but re-established as separate species by Bruce \& Bowman (1982). Although C. parva probably occurs in tropical eastern Pacific waters, $C$. parva of all published California studies is probably $C$. diminuta.

Although Cirolana diminuta had not been reported to attack fish until Stepien's study (1982, 1983a, b), other members of the Cirolanidae are well-known scavengers on dead fishes. Several studies have ques- tioned whether these attacks occurred on live, dying, or already-dead fishes (Nagano 1963, Sekiguchi 1982). The Pacific coast tidepool species C. harfordi Lockington 1877 has been described as a voracious scavenger on dead animal material and implicated as a possible predator. It has often been observed swarming over dead fishes, stripping the bones clean in a short time and locating its food by olfaction (Johnson 1976a, b, Lee \& Miller 1980). C. harfordi japonica Thielemann 1910 is known to scavenge on human cadavers and fish carcasses in Japan, in all seasons and in both midwater and near the seafloor (Nagano 1963). As in C. diminuta in the present study, $C$. harfordi japonica enters the 'prey' primarily through the gills and anus. Brusca (1980) has described 2 distinct feeding behaviors (scavenging and predatory) for the cirolanid isopod Excirolana braziliensis Richardson 1912 from western Mexico. Hendrickson (1958) reported cirolanids (Eurydice sp.) clinging to the eyelids of green sea turtles in Malaysia. Isopods have also been known to attack sharks caught in gill nets (Sekiguchi et al. 1981) and spiny lobsters (Sekiguchi 1982). Bird (1981) reported an apparently anomalous mass invasion of the cirolanid Natatolana borealis Lilljeborg 1851, that resulted in closure of the east Florida shark fishery in 1978. In this invasion, isopods preferentially fed on tissue high in blood content (e.g. heart and gills). Starck \& Shroeder (1965) indicated that biting isopods on Florida coral reefs parasitize fishes and also bite divers. Brusca (1981) postulated an evolutionary progression in flabelliferan isopods leading from the scavenging/occasional-predatory behavior of Cirolanidae, towards levels of increasing reliance upon living host fishes (primarily fish blood) for food (e.g. Aegidae), and finally to obligate parasitism in the Cymothoidae.

The gammarid amphipod Lysianassa holmesi (Lysiannassidae) often invaded the trap experiments along with the isopods. L. holmesi is a night-light swarmer and can swim a considerable distance off the bottom (J. L. Barnard pers. comm.). The opportunistic scavenging habits of lysianassid amphipods are well documented, especially in Arctic and Antarctic waters and in deep waters of temperate regions (Hessler et al. 1972, 1978, Vader 1972, Shulenberger \& Hessler 1974. Shulenberger \& Barnard 1976, Yayanos 1978, Thurston 1979, Ingram \& Hessler 1983). Large numbers can be collected by putting out carcasses or various types of baited traps (Walker 1903). Lysianassids can be very destructive to fishes and lobsters caught in stationary gear (Heldt 1952). Some species (Anonyx sp.) are known to prey on the lobster Homarus americanus Edwards 1837 (Scarratt 1965), and amphipods and isopods are known to consume spiny lobsters in Japan (Sekiguchi 1982). Bowman (1974) noted that 
amphipods have been reported to destroy bait left in lobster traps, a phenomenon confirmed by commercial fishermen surveyed in the present study. Hessler et al. (1978) observed that scavenging amphipods attacked whole frozen fish bait in the Philippine Trench, stripping the fish to the bone within $4.5 \mathrm{~h}$.

The commercial fishermen surveyed in this study indicated that attacking isopods and amphipods cause significant damage and dollar loss to the Pacific coast fishing industry (Table 3). Although this damage has been anecdotally reported, prior to the present study it was unknown whether fishes are attacked while still alive or after they are dead. It is probable that damage due to abrasion of fishes caught in gill net gear chemically attracts both the isopods and amphipods. Fishermen questioned stated that these attacks were more likely to occur when nets had been left out overnight although substantial fish destruction could also occur within a few hours.

In addition to the Pacific North American coast region, attacks by amphipods and isopods on fishes caught by commercial gill nets and set-lines are known to occur off Japan (Sekiguchi et al. 1981, Sekiguchi 1982), and in Arctic waters (W. G. Franzin pers. comm.). There is evidence that zooplankton migrators in tropical systems also attack fishes (Starck \& Schroeder 1965, Cohen 1983), indicating that this behavior is widespread. This phenomenon is probably common in most coastal areas of the world.

Collins et al. (1984) described an experiment conducted as part of an undergraduate course on Santa Catalina Island which used some of Stepien's (1982, 1983a, b, 1985) research ideas and techniques. They attempted to count ostracods attracted to the senorita Oxyjulis californicus by counting the number of luminescent specks on the fish in a darkened room. Their results were misleading since not all Vargula tsujii are luminescent at any given time, but luminesce sporadically and for lengths of time which vary greatly. Ostracods occurring in the gill chambers, anal region, and internally were not counted. This method of counting ostracods no doubt accounted for the large standard deviations reported by these authors. Collins et al. (1984) erroneously used a single 1 -way ANOVA to test 2 variables, ostracod attraction on sandy, rocky, and surfgrass habitats and at 2 different depths. Their conclusions that there were significant differences between these habitats appear unsubstantiated by their data and do not agree with those of the present study.

Migrating demersal zooplankton in both tropical and temperate systems are dominated by crustaceans, including ostracods, isopods, and amphipods which are highly vulnerable to predation by nocturnallyactive planktivorous fishes (Hobson 1968, 1974, Vivien
\& Peyrot-Clausade 1974, Hobson \& Chess 1976, 1979 , Alldredge \& King 1977, 1980, Hammer \& Zimmerman 1979, Hammer 1980, 1981, Hobson et al. 1981). These migrating crustaceans have been shown to significantly influence nocturnal fish behavior primarily due to their role as food for predatory species (Hobson 1968, 1974, Vivien \& Peyrot-Clausade 1974, Hobson \& Chess 1976, 1979, Hobson et al. 1981). However, examination of gut contents of adult kelpfish, kelpbass, and rock wrasse sacrificed immediately following the trap experiments indicate that these fish species do not eat the crustacean 'attackers' at night. These data are supported by in situ observations of unrestrained individuals and those in the trap experiments, as well as by Hobson et al. (1981). Rock wrasse, kelpfish, and kelpbass are primarily day feeders, although Hobson et al. (1981) state that subadult kelpbass sometimes feed on amphipods at night. As Hammer (1981, p. 278) comments, 'The prevalence (of nocturnal migration) in so many nearshore ecosystems leads one to assume that the disadvantages of migrating into the water column must be out-weighed by the potential advantages'.

Possible advantages include feeding, reproduction, molting, dispersal, and niche diversification (Smith \& Tyler 1972, Hobson \& Chess 1976, Alldredge \& King $1980,1985)$. Copulation, which usually follows ecdysis in isopods and amphipods, takes place in the water column in some Gammaridea (Bousfield 1973). Hammer (1980) found many gammaridean exuviae in his emergent trap samples which were also common in trap samples of the present study. The results of our experiments, however, suggest that lysianassid amphipods, as well as cirolanid isopods and myodocopan ostracods, may migrate primarily to feed. These ostracods and isopods attack relatively quiescent fishes located near the bottom and are most strongly attracted to injured individuals. They often 'dart in' for quick bites and often attack in swarms.

Various ways in which fishes may reduce the extent of these nocturnal attacks include rapid swimming, moving higher in the water column, burying themselves in the substrate, secreting a protective mucus envelope, and being cleaned by other animals. Most nocturnally-active planktivorous fishes at Santa Catalina Island swim in the water column, often rapidly, including adult olive rockfish Sebastes serranoides Eigenmann \& Eigenmann (Scorpaenidae), kelp rockfish Sebastes atrovirens Jordan \& Gilbert (Scorpaenidae), queenfish Seriphus politus Ayres (Sciaenidae), walleye surfperch Hyperprosopon argenteum Gibbons (Embiotocidae), and kelp perch Brachyistius frenatus Gill (Embiotocidae) (Hobson \& Chess 1976). Many day-active fishes also hover in the water column at night or move off the reefs, including top- 
smelt Atherinops affinis Ayres (Atherinidae) and pile surfperch Damalichthys vacca Girard (Embiotocidae) (Ebeling \& Bray 1976, Hobson et al. 1981). Our field experiments suggest that attack incidence is progressively lessened as fishes move up in the water column.

Earlier cage experiments conducted by Stepien (1982, 1983a, b, 1985) involving kelpfish confined in large cages containing rocks and algae (see 'Introduction') were completed successfully, without attacks, when the cages were suspended $10 \mathrm{~m}$ or more off the bottom. Kelpfish in cages located within $7 \mathrm{~m}$ of the bottom were occasionally attacked by crustacean zooplankton when left out for several consecutive nights. It was also found that cages located near dock lights attracted the attacking crustaceans, even when located $10 \mathrm{~m}$ off the bottom.

The well-known nocturnal burial in sand by temperate and tropical wrasses (Labridae) may be an adaptation for avoiding crustacean zooplankton attacks. Rock wrasse Halichoeres semicinctus and senorita Oxyjulis californica are labrids at Catalina Island which commonly bury themselves at night, with only the head protruding (Limbaugh 1955, Feder et al. 1974, Fitch \& Lavenberg 1975, Hobson et al. 1981). Fishes which hide in rock crevices at night may be cleaned by other species. The red rock shrimp Lysmata californica Stimpson 1860 is a fish cleaner (Limbaugh 1961) commonly found in rock crevices at Catalina Island. Tropical banded coral shrimps Stenopus spp. have been observed to remove skin parasites from large sleeping parrot fishes at night (Starck \& Shroeder 1965)

Secretion of mucus envelopes at night by many parrot fishes and tropical wrasses may protect them from predators (Winn 1955, Bardach et al. 1959, Winn \& Bardach 1960, Starck \& Davis 1966, Casimir \& Fricke 1971, Collette \& Talbot 1972). Such mucus cocoon secretion is characteristic of parrot fishes which suffer injury or distress (Winn 1955, Starck \& Davis 1966). Smith \& Tyler (1972) observed 1 parrot fish individual on a reef in the Virgin Islands that formed a mucus envelope on some nights, but not on others. In the present study, some kelpbed fishes in trap experiments were observed to secrete large quantities of mucus. These included kelpfish, rock wrasse, and senorita.

Morphological features of certain fishes may help prevent severe attacks. These may include welldeveloped scalation and gills which are located far back under the operculum. Gills of this design may help to prevent attachment of the zooplankton at a site where they often cause extensive damage. Many fishes that rest nocturnally in open areas near the benthos apparently avoid crustacean zooplankton bites by shaking them off and by moving to other locations, as observed for blacksmith, garibaldi, kelpbass, sandbass, and kelpfish.
In conclusion, we have provided additional evidence that some species of nocturnally emergent crustacean zooplankton may significantly influence nocturnal fish distribution and behavior. One of us (C.S.) is currently testing possible avoidance mechanisms in temperate and tropical fishes. Nocturnal emergence into the water column, where the plankton are themselves subject to predation by fishes, appears to be a feeding adaptation of the ostracod and isopod species discussed in this paper. Thus, 1 role of these zooplankton in nearshore marine systems may be analagous to that of swarms of biting terrestrial dipteran insects.

Acknowledgements. We gratefully acknowledge Anne Cohen for identifying the ostracods and providing information on their taxonomy and natural history. Paul Delaney, John Chapman, and Ernest Iverson assisted in the isopod and amphipod identifications. J. L. Barnard provided information on the taxonomy and natural history of Lysianassa spp. Steven Naffziger, Donald Wilkie, Robert Moore, and Richard Wright assisted in night dives and trap experiments. Catalina Marine Science Center provided research laboratory space and diving facilities. Robert Provin assisted in drawing the figures. Robson Collins and A. Rucker Hartmann of the California Department of Fish and Game provided information on attacks in commercial fisheries and contacts with local commercial fishermen. John Richards, Christopher Toole, and Art Flechsig of California Sea Grant Marine Advisory Program provided additional contacts and information. H. B. Parks of National Marine Fisheries and W. G. Franzin of the Canadian Fisheries and Oceans Department also assisted in relating useful information. Tony West of the California Gillnetters Association printed the survey in their newsletter and obtained the assistance of the Pacific Coast Federation of Fishermen Association. G. Randy Miller, Robert Lombard, Mike Nicholas, Robert Everett, Philip Begul, Ed Wayman, Tony West, Zeke Grader, Henry Wakefield, Paul Gregory, Jack Phillips, and Nello Castagnola participated in the survey. This manuscript benefited substantially from critical reviews by Alice L. Alldredge, Gary J. Brusca, Anne C. Cohen, and Gerald J. Bakus

\section{LITERATURE CITED}

Alldredge, A. L., King, J. M. (1977). Distribution, abundance and substrate preference of demersal reef zooplankton at Lizard Island Lagoon, Great Barrier Reef. Mar. Biol. 41: 317-333

Alldredge, A. L., King, J. M. (1980). Effects of moonlight on the vertical migration patterns of demersal zooplankton. J. exp. mar. Biol. Ecol. 44: 133-156

Alldredge, A. L., King, J. M. (1985). The distance demersal zooplankton migrate above the benthos: Implications for predation. Mar. Biol. 84: 253-260

Barnard, J. L. (1955). Notes on the amphipod genus Aruga with the description of a new species. Bull. Sth. Calif. Acad. Sci. 55: 35-43

Bardach, J. E., Winn, H. E., Menzel, D. W. (1959). The role of senses in the feeding of the nocturnal reef predators $G y m-$ nothorax moringa and G. vicinus. Copeia 1959: 133-139

Bird, P. M. (1981). The occurrence of Cirolana borealis 
(Isopoda) in the hearts of sharks from Atlantic coastal waters of Florida. Fish. Bull. U.S. 79 (2) : 376-383

Bousfield, E. L. (1973). Shallow water gammaridean Amphipoda of New England. Comell Univ. Press, Ithaca

Bowman, T E. (1974). The sea flea Dolobrotus mardeni n. gen., n. sp., a deep-water American lobster bait scavenger (Amphipoda: Eusiridae). Proc. Biol. Soc. Wash. 87: 129-138

Bruce, N. L., Bowman, T. E. (1982). The status of Cirolana parva Hansen, 1890 (Crustacea, Isopoda, Cirolanidae) with notes on its distribution. Proc. Biol. Soc. Wash. 95 (2): 325-333

Brusca, R. C. (1980). Common intertidal invertebrates of the Gulf of California, 2nd Ed. Univ. Arizona Press, Tucson

Brusca, R. C. (1981). A monograph on the Isopoda Cymothoidae (Crustacea) of the eastern Pacific. Zool. J. Linn. Soc. 73 (2): 117-199

Brusca, R. C., Iverson, E. (1985). A guide to the marine isopod crustaceans of Pacific Costa Rica. Bull. Rev. Biol. Trop. (in press)

Casimar, M. J., Fricke, H. W. (1971). Zur Funktion, Morphologie und Histochemie der Schwanzdrüse bei Röhrenaalen (Pisces, Apodes, Heterocongridae). Mar. Biol. 9 (4): $334-346$

Cohen, A. C. (1983). Rearing and postembryonic development of the myodocopid ostracod Skogsbergia lerneri from coral reefs of Belize and the Bahamas. J. Crust. Biol. 3 (2): 235-256

Collette, B. B., Talbot, F. H. (1972). Activity patterns of coral reef fishes with emphasis on nocturnal-diumal changeover. In: Collette, B. B., Earle, S. S. (ed.) Results of the Tektite program: Ecology of coral reef fishes. Bull. Nat. Hist. Mus., L. A. Cty. 14: 98-124

Collins, K. J., Ralston, S., Filak, T., Bivens, M. (1984). The susceptibility of Oxyjulis californica to attack by ostracods on three substrates: Research note. Bull. Sth. Calif. Acad. Sci. 83 (1): 53-56

Ebeling, A. W., Bray, R. N. (1976). Day versus night activity of reef fishes in a kelp forest off Santa Barbara, California. Fish. Bull. U.S. 74; 703-717

Emery, A. R. (1968). Preliminary observations on coral reef plankton. Limnol. Oceanogr. 13: 293-303

Eschmeyer, W. N., Herald, E. S., Hammann, H. (1983). A field guide to Pacific Coast fishes of Northern America. Houghton Mifflin Company, Boston

Feder, H. M., Turner, C. H., Limbaugh, C. (1974). Observations on the fishes associated with kelp beds in southern California. Calif. Fish Game Fish Bull. 160: 1-144

Felder, D. L. (1982). A report of the ostracod Vargula harveyi Kornicker and King, 1965 (Myodocopida, Cypridinidae) in the southern Bahamas and its implication in luminescence of a ghost crab, Ocypode quadrata (Fabricius, 1787). Crustaceana $42(2)$ : 222-224

Fitch, J. E. (1974). Offshore fishes of Califormia. Publ. Calif. Fish Game, Sacramento, p. 35-36

Fitch, J. E., Laveriberg, R. J. (1975). Tidepool and nearshore fishes of California, Univ. Calif. Press, Berkeley

Hammer, R. M. (1980). Ecology of kelp forest denersal zooplankton, Ph. D. dissertation, Univ. Southern California

Hammer, R. M. (1981). Day-night differences in the emergence of demersal zooplankton from a sand substrate in a kelp forest. Mar Biol. 62; 275-280

Hammer, R. M., Zimmerman, R. C. (1979). Species of demersal zooplankton inhabiting a kelp forest ecosystem off Santa Catalina Island. California. Bull. Sth. Calif. Acad. Sci. 78: 199-206

Harding, J. (1966). Myodocopan ostracods from the gills and nostrils of fishes. In: Barnes, H. (ed.) Some contemporary studies in marine science. George Allen and Unwin, London, p. 369-374

Heldt, J. H. (1952). Note sur quelques petits Crustaces ichthyophages. Bull. soc. Sci. Nat. Tunisie, 5: 111-113

Hendrickson, J. R. (1958). The green sea turtle, Chelonia mydas (Linn.) in Malaya and Sarawak. Proc, zool. Soc. Lond. 130 (4): 455-535

Hessler, R. R., Issacs, J. D., Mills, E. L. (1972). Giant amphipod from the abyssal Pacific ocean. Science 175:636-637

Hessler, R. R., Ingram, C. L., Yayanos, A. A., Burnett, B. R. (1978). Scavenging amphipods from the floor of the Philippine Trench. Deep Sea Res. 25: 1029-1047

Hobson, E. S. (1968). Predatory behavior of some shore fishes in the Gulf of California. U.S. Fish Wildl. Serv., Res. Rep. 73: $1-92$

Hobson, E. S. (1974). Feeding relationships of teleostean fishes on coral reefs in Kona, Hawaii. Fish. Bull. U.S., 72 : 915-1031

Hobson, E. S., Chess, J. R. (1976). Trophic interactions among fishes and zooplankters near shore at Santa Catalina Island, California. Fish. Bull. U.S. 74: 567-598

Hobson, E. S., Chess, J. R. (1979). Zooplankters that emerge from the lagoon floor at night at Kure and Midway Atolls, Hawaii. Fish. Bull. U.S. 77: 275-280

Hobson, E. S., McFarlane, W. N., Chess, J. R. (1981). Crepuscular and nocturnal activities of Califomian nearshore fishes, with consideration of their scoptic visual pigments and the photic environment. Fish. Bull. U.S. 79 (1): 1-30

Ingram, C. L., Hessler, R. R. (1983). Distribution and behavior of scavenging amphipods from the central North Pacific. Deep Sea Res. 25: 1029-1047

Johnson, W. S., (1976a). Biology and population dynamics of the intertidal isopod Cirolana harfordi. Mar. Biol. 36: 343-350

Johnson, W. S. (1976b). Population energetics of the intertidal isopod, Cirolana harfordi. Mar. Biol. 36: 351-357

Kornicker, L. S., Baker, J. H. (1977). Vargula tsujii, a new species of luminescent ostracoda from lower and southern California (Myodocopa: Cypridininae). Proc. Biol. Soc. Wash. 90 (2): 218-231

Kretzler, J. E. (1984). Echinophilus xiphidion, new species (Ostracoda, Paradoxostomatidae) parasitic on regular echinoids of the northeastern Pacific. J. Crust. Biol., 4 (2): $333-340$

Kussakin, O. G. (1979). Marine and brackish-water Isopoda of the cold and temperate waters of the Northern Hemisphere. Vol. I. Flabellifera. Opredeliteli po faune SSSR, Adad. nauk SSSR, (Acad. Sci. USSR, Zoology), No. 122 (in Russian)

Lee, W. L., Miller, M. A. (1980). Isopoda and Tanaidacea: The isopods and allies. In: Morries, R. H., Abbott, D. P., Haderlie, E. C. (ed.) Intertidal invertebrates of California. Stanford Univ. Press, Stanford, p. 536-558

Limbaugh, C. (1955). Fish life in the kelpbeds and the effects of kelp harvestng. Univ. Calif. Inst. Mar. Res. Ref. 55 (9): $1-158$

Limbaugh, C. (1961). Cleaning symbiosis. Scient. Am. 205: $42-49$

Menzies, R. J. (1962). The marine isopod fauna of Bahia de San Quintin, Baja California, Mexico. Pacif. Nat. 3: $337-348$

Menzies, R. J., Glynn, P. L. (1968). The common marine isopod Crustacea of Puerto Rico. Studies on the fauna of Curacao and other Caribbean islands. 27: 1-133

Monod, T. (1923). Notes carcinologiques (Parasites et commensaux). Bull. Inst. oceanogr Monaco 427: 1-5 
Moreira, P. S., Sadowsky, V. (1978). An annotated bibliography of parasitic Isopoda (Crustacea) of Chondrichthyes. Bolm. Inst. Oceanogr., Sao Paulo, 27 (2): 95-152

Nagano, T. (1963). Rapid destruction of submerged cadavers by tiny marine animals. Wakayama Med. Rep. 8 (1): 31-39

Porter, J. W. (1974). Zooplankton feeding by the Caribbean reef building coral Montastrea cavernosa. Proc. 2nd Int. Coral Reef Symp., Brisbane 1: 111-125

Porter, J. W., Porter, K. G. (1977). Quantitative sampling of demersal zooplankton migrating from different coral reef substrates. Limnol. Oceanogr. 22: 553-555

Richardson, H. (1904). Contributions to the natural history of the Isopoda. (Introduction). Proc. U.S. natn. Mus. 27: 1-89

Robertson, A. I., Howard, R. K. (1978). Diel trophic interactions between vertically migrating zooplankton and their fish predators in an eelgrass community. Mar. Biol. 48: $207-213$

Sars, G. O. (1897). An account of the Crustacea of Norway, with short descriptions and figures of all the species. Vol. II., Isopoda, Part III, IV. Anthuridae, Gnathiidae, Aegidae, Cirolanidae, Limnoriidae. Bergens Mus. Årb. 1897: 43-80

Scarratt, D. J. (1965). Predation on lobsters (Homarus americanus) by Anonyx sp. (Crustacea, Amphipoda). J. Fish. Res. Bd Can. 22: 1103-1104

Sekiguchi, H. (1982). Scavenging amphipods and isopods attacking the spiny lobster caught in a gill-net. Rep. Fish. Res. Lab., Mie Univ. 3: 21-30

Sekiguchi, H., Yamaguchi, Y., Kobayashi, H. (1981). Bathynomus (Isopoda: Cirolanidae) attacking sharks caught in a gill net. Bull. Fac. Fish., Mie. Univ. 8: 11-17

Shulenberger, E., Barnard, J. L. (1976). Amphipods from an abyssal trap set in the North Pacific Gyre. Crustaceana 31 (3): 241-258

Shulenberger, E., Hessler, R. R. (1974). Scavenging abyssal benthic amphipods trapped under oligotrophic central North Pacific Gyre waters. Mar. Biol. 28: 185-187

Smith, C. L., Tyler, J. C. (1972). Space resource sharing in a coral reef fish community. In: Collette, B. B., Earle, S. A. (ed.) Results of the Tektite program: Ecology of coral reef fishes. Bull. Nat. Hist., L. A. Cty. 14: 125-170

Sokal, R. R., Rohlf, F. J. (1981). Biometry: The principle and practice of statistics in biological research, 2nd ed. W. H. Freeman and Co., San Francisco

Starck, W. A., Davis, W. P. (1966). Night habits of fishes of Alligator Reef, Florida. Ichthyologica 38: 313-356

Starck, W. A., Schroeder, R. E. (1965). A coral reef at night. Sea Front. 11 (2): 66-79

Stepien, C. A. (1982). Nocturnal predation on caged fishes by ostracods and isopods. Res. Rep., Catalina Mar. Sci. Center, Inst. for Mar. and Coast. Stud., Univ. Southem California 1982: 9-11

Stepien, C. A. (1983a). Nocturnal attacks on caged fishes by crustacean zooplankters. Abstracts of Sth. Calif. Acad. Sci. Ann. Meeting, Fullerton, Calif. 1983: 9

Stepien, C. A. (1983b). Nocturnal predation on caged fishes by ostracods and isopods. Amer. Soc. of Ichthyologists and Herpetologists 63rd Ann. Meeting Program and Abstracts, Tallahasse, Fla. 1983: 23

Stepien, C. A. (1985). Regulation of color pattern in the giant kelpfish Heterostichus rostratus Girard (Clinidae): with notes on its ecology and life history. Ph. D. Dissertation, Univ. Southern California

Thurston, M. (1979). Scavenging abyssal amphipods from the northeast Atlantic ocean. Mar. Biol. 51: 55-68

vader, W. (1972). Notes on Norwegian marine amphipoda. 5. New records of Leptamphopus sarsii (Callioplidae). Sarsia 50: $25-28$

Vivien, M. L., Peyrot-Clausade, M. (1974). A comparative study of the feeding behavior of three coral reef fishes (Holocentridae), with special reference to polychaetes of the reef cryptofauna as prey. Proc. 2nd Int. Coral Reef Symp., Brisbane 1: 179-192

Walker, A. O. (1903). Amphipoda of the 'Southern Cross' Antarctic expedition. J. Linn. Soc. 29: 38-64

Winn, H. E. (1955). Formation of a mucous envelope at night by parrot fishes. Zoologica, N. Y. 40: 145-148

Winn, H. E., Bardach, J. E. (1960). Some aspects of the comparative biology of parrot fishes at Bermuda. Zoologica, $N$. Y. $45: 29-34$

Yayanos, A. A. (1978). Recovery and maintenance of live amphipods at a pressure of 580 bars from an ocean depth of 5700 meters. Science 200: 1056-1058 